\title{
Climate change potential effects on grapevine bioclimatic indices: A case study for the Portuguese demarcated Douro Region (Portugal)
}

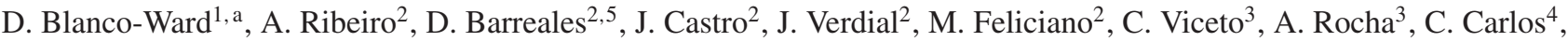 \\ C. Silveira ${ }^{1}$, and A. Miranda ${ }^{1}$ \\ ${ }^{1}$ Department of Environment and Planning (DAO) \& Centre for Environmental and Marine Studies (CESAM), Aveiro University, \\ 3810-193 Aveiro, Portugal \\ ${ }^{2}$ Mountain Research Centre (CIMO), School of Agriculture, Polytechnic Institute of Bragança, Campus de Santa Apolónia, \\ 5300-253 Bragança, Portugal \\ ${ }^{3}$ Physics Department \& CESAM, Aveiro University, 3810-193 Aveiro, Portugal \\ ${ }^{4}$ Association for the Development of Viticulture in the Douro Region (ADVID), 5050106 Peso da Régua, Portugal \\ ${ }^{5}$ Department of Engineering and Agricultural Sciences, University of Leon, 24071 Portugal Avenue 41, León, Spain
}

\begin{abstract}
In this work, bioclimatic parameters and indices relevant to the grapevine are estimated for the years 2000 (recent-pat), 2049 (medium-term future) and 2097 (long-term future), based on very high resolution $(1 \mathrm{~km} \times 1 \mathrm{~km})$ MPI-WRF RCP8.5 climate simulations. The selected parameters and indices are the mean temperature during the grapevine growing season period (April to October, Tgs), the cumulative rainfall during the grapevine growing season period (Pgs), the Winkler index (WI), the Huglin heliothermic index (HI), the night cold index (CI) and the dryness index (DI). In general, a significant increase in mean temperature during the grapevine growing season period is observed, together with a significant decrease in precipitation. The recent-past WI is associated with the production of high-quality wines; the higher values predicted for the future represent intensive production of wines of intermediate quality. The HI shows the passage of a grapevine growing region considered as temperate-warm to a warm category of higher helio-thermicity. The recent-past CI indicates very cool conditions (associated with quality wines), while in the future there is a tendency for temperate or warmer nights. Finally, DI indicates an increase in water stress considered already high under the recent-past climate conditions. These results point to an increased climatic stress on the Douro region wine production and increased vulnerability of its vine varieties, providing evidence to support strategies aimed to preserve the high-quality wines in the region and their typicality in a sustainable way.
\end{abstract}

\section{Introduction}

Year-to-year meteorological variations affect the yield and the optimal environmental conditions for the grape to ripe and, therefore, whether wine typicity for a given 'terroir' or grapevine growing region will be correctly expressed to achieve its full potential. This is known as the "vintage effect" with climate having a greater impact on yield and quality than other environmental factors such as soil type or grapevine variety. In this sense, it is already known that an increase of temperature produces an advance in phenology, which in turn, could have advantageous effects in northern or Atlantic conditions but be detrimental under Mediterranean conditions: as the grapes are exposed to higher temperatures due both to climate change and advanced phenology, the supply of metabolites to the grape is altered, generally causing greater sugar accumulation and higher alcohol levels, lower acidity and variable effects on different aromas and secondary metabolites [1].

Besides climate parameters such as the mean temperature or the accumulated precipitation over the

a e-mail: dblancoward@ua.pt grapevine growing season, bioclimatic indices have also been extensively supported as useful metrics to assess the climatic potential of a region for viticulture. For instance, the Winkler index (WI) was used to divide California into five climatic regions with different grape variety potential [2], and it has often been used widely in many countries afterwards. However, the WI applicability as an effective bioclimatic zoning tool has been somewhat limited to the fact that it does not consider other important factors such atmospheric humidity or plant water stress [3]. A more generally applicable procedure was proposed with the Multicriteria Climatic Classification System (MCC System) for grape growing regions worldwide which associates heat accumulation, soil water availability and ripening conditions to grape quality and wine typeness potential [4].

Bioclimatic metrics for viticultural zoning can also be used to assess the potential impacts of climate change on wine producing regions. For instance, the MCC System has been already considered to assess the impact of climate change on the suitability for wine production across Europe. The indices were calculated from climate 
variables obtained from simulations with a grid size of about $25 \mathrm{~km}$ performed with the regional climate model COSMO-CLM for the recent-past climate (1960-2000) and for the 21st century (2011-2040, 2041-2070 and 2071-2100) under the Intergovernmental Panel on Climate Change Special Report on Emission Scenarios (IPCCSRES) B1 and A1B. All simulations were forced by ECHAM5/MPI-OM1 boundary conditions. The results of this study indicated an increased soil water deficit and cumulative thermal effects during the growing season in southern Europe, which could imply negative effects for wine production for these areas unless suitable adaptation measurements (e.g. rootstock and variety selection, training system, irrigation) are taken. In contrast, western and central Europe could benefit with higher quality potential for the grape and even new potential areas for wine production [5].

In another study, the atmospheric variables taken from coupled global and regional climate models (GCMRCMs) simulations in combination with the MCC system were also used to assess present and future scenarios for the Portuguese grapevine growing regions. For present scenarios (1950-2000), the WorldClim project $1 \mathrm{~km}$ high resolution dataset [6], validated with E-OBS observational data [7] was used. To assess the impacts of climate change on future viticulture suitability in Portugal, the period 2014-2070 under the IPCC-SRES A1B was chosen. An ensemble of $13 \mathrm{RCM}$ simulations driven by 3 different GCMs produced by the ENSEMBLES project [8] was selected. To pass from the coarse grid RCM resolution $0.22^{\circ} \times 0.22^{\circ}(\sim 25 \mathrm{~km})$ to the $1 \mathrm{~km}$ grid size of the WorldClim baseline dataset, a bi-cubical interpolation (empirical pattern downscaling or "delta" method) was used. The final results illustrated significant changes in the current bioclimatic viticultural Portuguese zones as they depict a lower bioclimatic diversity and a more homogenous warm and dry climate for most Portuguese wine regions [8].

The purpose of this study is to evaluate whether very high $1 \times 1 \mathrm{~km}$ resolution MPI-ESM-LR dynamically downscaled simulations can be used successfully as a zoning bioclimatic tool in the Portuguese Douro Demarcated Region (DDR). The Weather Research and Forecasting (WRF) model is used as the dynamical downscaling tool to obtain regional climate information from the GCM simulations. Mid-term and long-term future simulations are also performed to assess the possible impacts of climate changes in the study area under the IPCC newer RCP8.5 which is the closest to 'business as usual' scenario of fossil use $[9,10]$.

\section{The study area}

The Portuguese Douro Demarcated Region (DDR) runs along both margins of the Douro River from its midcourse in the East up to the border with Spain in the West. The western most area of the region is located $70 \mathrm{~km}$ from the Atlantic Ocean. The Douro Valley extends along $90 \mathrm{~km}$ in the West-East direction and along $50 \mathrm{~km}$ in the NorthSouth direction (Fig. 1). The landscape is characterized by mountainous terrain, rising above the Douro River and its tributaries, with moderate to steep slopes and varying exposures. The geology of the Douro Valley is dominated by schistose-layered rock, oriented nearly vertical, with

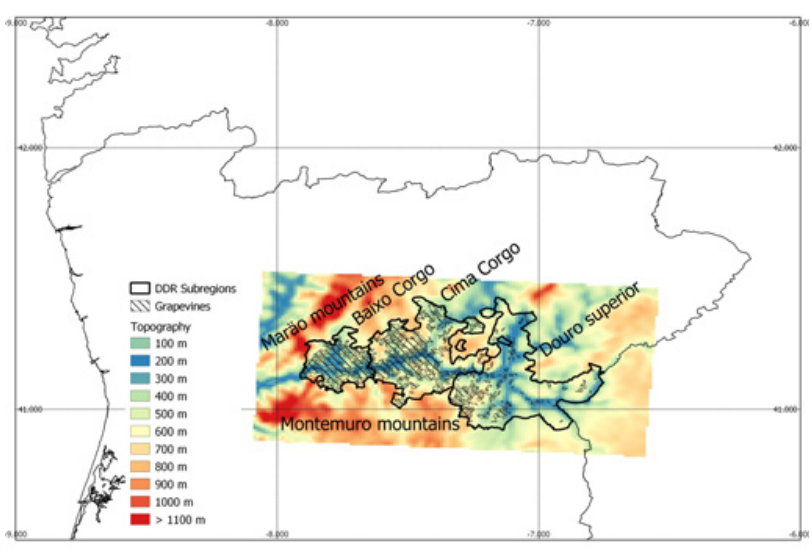

Figure 1. The Portuguese Douro Demarcated Region (DDR) with sub-regional subdivisions Baixo Corgo, Cima Corgo and Douro Superior and grapevine cultivated areas.

some outcrops of granite. The average elevation over the entire region is $443 \mathrm{~m}$ but ranges from a low near $40 \mathrm{~m}$ to a high of just over 1,400 m [11].

The region covers approximately 250,000 hectares with vineyard area representing roughly 43,480 hectares, $17.4 \%$ of the total land area. The DDR is divided into three sub-regions: Baixo Corgo with the smaller area $(45,000 \mathrm{ha})$, Cima Corgo with an intermediate extension (95,000 ha), and Douro Superior with the largest extension (110,000 ha). The vineyard figures for these sub-regions are 13,368 ha, 20,270 ha and 9,842 ha respectively [12]. The vineyards are arranged in various terraced configurations or planted according to the natural slope of the land. The terraces were created and perfected throughout the centuries enabling man to cultivate vines on the steepest slopes.

The DDR has a Mediterranean climate, with highly variable rainfall events, concentrated in winter months, and hot summers. It is sheltered from Atlantic wet and cold winds by two mountain ranges, Marão and Montemuro, located at its western border. Temperature increases, and precipitation decreases from West to East. The westernmost sub-region inside the Douro Valley (Baixo Corgo) is nearer to the Atlantic Ocean and therefore more affected by the moist maritime winds. The eastern most areas within the Douro Superior sub-region are more distant from the Atlantic Ocean therefore having a more continental climate influence. The region is generally classified as a warm temperate climate (Köppen Csb), with average annual temperatures during 1980-2009 of $15.4{ }^{\circ} \mathrm{C}$, average daily minima temperatures $\left(T_{\min }\right)$ in the coldest month dropping to $2.7^{\circ} \mathrm{C}$, and average daily maxima temperatures $\left(T_{\max }\right)$ in the warmest month reaching $32.1^{\circ} \mathrm{C}$ [13]. Mean growing season temperature (GST) from April to September for the same climatological period is $20.6^{\circ} \mathrm{C}$. Growing season precipitation (GSP) has a mean value of $193 \mathrm{~mm}$, representing 30\% of the annual total $(624 \mathrm{~mm})$. The average precipitation of the driest month (July) is just $11.2 \mathrm{~mm}$. Low precipitation values along with high temperatures and high radiation exposure give rise to situations of intense summer plant-soil-water stress, particularly in the Cima Corgo and Douro Superior sub-regions [14]. 
Considering three meteorological stations representative of the three DDR sub-regions during 1980-2009, the Huglin Index (HI) in the area averaged 2,740 units whereas the dryness index (DI) had a mean value of $-126 \mathrm{~mm}$, and the cool night index (CI) one of $13.6^{\circ} \mathrm{C}$. In the Geoviticulture MCC System, the DDR climate is currently classified as $\mathrm{HI}+2 / \mathrm{DI}+2 / \mathrm{CI}+1$ (Warm/Very dry/Cool nights) [4-15]. Other renowned grape growing regions falling under this classification are the Napa Valley (US) and the Mildura wine distric (Australia) [4]. Although the Geoviculture MCC system is generally accepted as a useful tool to describe the climate of grape growing regions globally, it is advisable to keep in mind that there might also be considerable variations at the mesoscale due to different factors such as topography or distance to the sea [16]. In fact, values given for the Régua station within the Baixo corgo sub-region during $1951-80$ were $2489^{\circ} \mathrm{C}^{\text {day }^{-1}}$ for $\mathrm{HI}-$ close to the $\mathrm{HI}+12400^{\circ} \mathrm{C}$ day- 1 limit of the temperate warm class-, $-37 \mathrm{~mm}$ for DI - belonging to the DI +1 or moderately dry class-, and $12.8^{\circ} \mathrm{C}$ for $\mathrm{CI}-$ falling inside to the same $\mathrm{CI}+1$ category as the overall more recent classification [17].

\section{Data and methods}

\subsection{High resolution $1 \times 1 \mathrm{~km}$ WRF-MPI simulations}

Marta-Almeida et al. [18] performed an ensemble of WRF high-resolution $9 \times 9 \mathrm{~km}$ climate simulations driven the Max Planck Institute Earth System - low resolution model (MPI-ESM-LR). The MPI-ESM-LR is a global Earth System Model developed by the Max-Planck Institute, with $1.9^{\circ}$ resolution [19] which corresponds to about $160 \mathrm{~km}$ horizontal resolution. This model participated in the Coupled Model Intercomparison Project Phase 5 (CMIP5), which uses new emission scenarios, namely the RCPs. In this study, RCP8.5, defined by a radiative forcing of $8.5 \mathrm{~W} \mathrm{~m}-2$ by 2100 and a continuous increase after this year, was selected. RCP 8.5 provides an updated and revised quantification of the original IPCC A2 SRES scenario $[9,10]$.

WRF high-resolution climate simulations were performed for 20-year periods as adopted by the IPCC 5th Assessment Report [20], namely 1986-2005 for the recent-past, 2046-2065 for the mid-term future and 2081-2100 for the long-term future climate. These simulations were originally implemented for three nested domains with increasing horizontal resolutions, namely 81, 27 and $9 \mathrm{~km}$ (Fig. 2). Validation of the WRF recentpast with observational temperature and precipitation datasets for the Iberian Peninsula provided acceptable comparisons of the probability distributions of temperature and precipitation [18]. A selection of a representative warmest year for each of the 20-year series was made to perform the very high-resolution $1 \times 1 \mathrm{~km}$ simulations constricted to the DDR study area as the procedure to generate them makes uses of intensive memory and storage computer resources being only approachable in a HighPerformance Computing (HPC) system. The selected years were 2000, 2049 and 2097. The time resolution for these simulations was 1 hour.

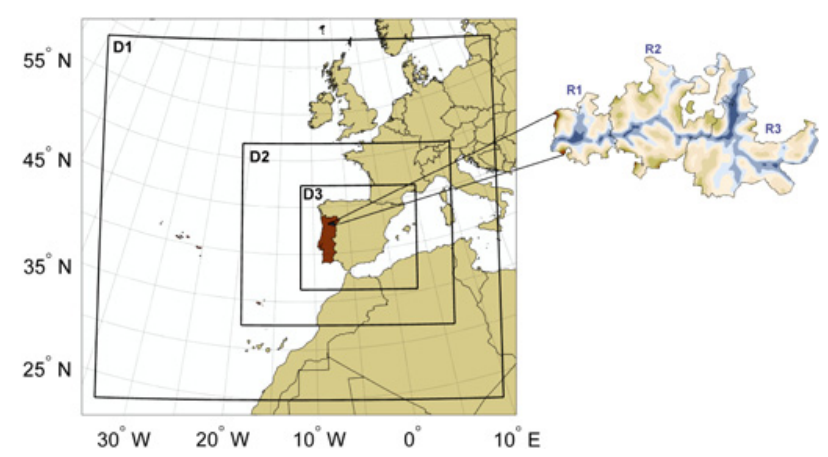

Figure 2. Nested model domains used in the regional WRF implementation with resolutions of 81 (D1), 27 (D2) 9 (D3) and 1 (D4) $\mathrm{km}^{2}$.

\subsection{Climate parameters and indices}

Two specific grapevine climate parameters and four bioclimatic indices were selected: the April to October growing season mean temperature (Tgs), the April to October growing season accumulated precipitation (Pgs), the Winkler index (WI), the Heliothermal index of Huglin (HI), the cool night index (CI) and the dryness index (DI). The last four bioclimatic indices are commonly used to characterize grapevine growing areas worldwide in a standardized way and as an agronomic zoning tool $[2,4,16]$.

The Winkler index (WI) is the sum of the daily average temperatures above a threshold temperature of $10^{\circ} \mathrm{C}$ considered the active grapevine temperature (the temperature above which it activates its vegetative cycle) along the growing season. This index is usually calculated from monthly data:

$$
\begin{aligned}
W I & =\sum_{\text {April } 1 \mathrm{st}}^{\text {October } 31 \mathrm{st}}\left(T_{\mathrm{avg}}-10^{\circ} \mathrm{C}\right), T_{\mathrm{avg}} \geq 10^{\circ} \mathrm{C} \\
T_{\text {avg }} & =\frac{T_{\max }+T_{\min }}{2}
\end{aligned}
$$

The Huglin index (HI) provides information regarding heliothermal and sugar potential. It is very much correlated with the Thermal Index of Winkler $(\mathrm{r} 2=0.98$ over 97 grape-growing regions worldwide) but, according to Tonietto et al. [4], is more pertinent to the qualitative factors (e.g. berry sugar potential) [4].

$$
\begin{aligned}
H I & =\sum_{\text {April 1st }}^{\text {September } 30 \text { th }} \frac{\left(T_{\max }-10^{\circ} \mathrm{C}\right)+\left(T_{\text {avg }}-10^{\circ} \mathrm{C}\right)}{2} d \\
T_{\text {avg }} & =\frac{T_{\max }+T_{\min }}{2}
\end{aligned}
$$

Where again, $T_{\text {avg }}$ is the mean air temperature $\left({ }^{\circ} \mathrm{C}\right), T_{\max }$ is the maximum air temperature $\left({ }^{\circ} \mathrm{C}\right), \mathrm{d}$ is length of day coefficient ranging from 1.02 to 1.06 between $40^{\circ}$ and $50^{\circ}$ of latitude. A value of 1.02 was assumed for a latitude between $40^{\circ} 01^{\prime}$ and $42^{\circ} 00^{\prime}$. This index is usually also calculated from monthly climatic means.

The purpose of cool night index (CI) is to improve the assessment on the grape qualitative potentials, notably in relation to secondary metabolites (polyphenols, aromas) in grapes [4]:

$$
C I=\sum_{\text {September 1st }}^{\text {September 30st }} \frac{T_{\min }}{30}
$$


Finally, the dryness index (DI) indicates the potential water availability in the soil, related to the level of dryness in a region. It is also associated with the level of grape ripening and wine quality [4].

$$
W=W_{0}-P-T_{v}-E_{s}
$$

For intercomparison reasons, DI is also calculated on a monthly basis during the same period used for HI (April $1^{\text {st }}$ to September $30^{\text {th }}$ ), which is acceptable for most of grape growing regions in the northern hemisphere. $\mathrm{W}$ is the estimate of soil water reserve at the end of the April $1^{\text {st }}$ September $30^{\text {th }}$ modelled growing season period, $\mathrm{W}_{0}$ is the initial soil water reserve, which can be accessed by the vine roots, $\mathrm{P}$ the total monthly precipitation, $\mathrm{T}_{v}$ the potential transpiration of the vineyard and $E_{\mathrm{s}}$ the direct evaporation from the soil. To compute $T_{v}$ and $E_{S}$ is also necessary to compute the monthly total potential evapotranspiration. This is usually done by the Penman-Monteith method but as only temperature and precipitation records were available, it was approximated by the Hargreaves method, which produces comparable results in arid and semiarid environments and requires temperature data only [21]. The result is given as $\mathrm{mm}$ of water in the soil. The initial $\mathrm{W}_{0}$ is usually taken as $200 \mathrm{~mm}$ [4].

\section{Results}

Figure 3 illustrates the grapevine mean growing season temperature (Tgs), the precipitation (Pgs) and the Winkler index (WI) thematic layers derived from the very high-resolution $1 \mathrm{~km} \times 1 \mathrm{~km}$ WRF-MPI RCP 8.5 hourly simulations for the selected representative recent-past (2000), mid-term future (2049) and long-term future (2097) years in the Portuguese Douro Demarcated Region (DDR). For the year 2000 recent-past simulation, most cell values within the DDR are associated with the temperate and warm class with some occurrence of the intermediate class too for Tgs, rainfall values between $200-400 \mathrm{~mm}$ for Pgs, and a diverse set of WI regions present ranging from Ib to $\mathrm{V}$. The higher Tgs values and WI regions are associated with the lower altitudes across the Douro river valley and its tributaries also increasing their presence as they are more distant from the Atlantic influence towards the east. The Pgs spatial pattern results both from the yearly storm distribution and the variate topographical characteristics present in the area.

For the year 2049 mid-term simulation, Tgs intermediate conditions decrease their presence whereas warm conditions become more frequent, there is an increase of cells with only $100-200 \mathrm{~mm}$ of Pgs, and WI region $1 \mathrm{~b}$ and II reduce their area at the same time IV and V increase their coverage.

Finally, the year 2097 long-term MPI-WRF future simulation indicates the disappearance of temperate conditions which are substituted either by warm or very warm areas, Pgs values fall below $200 \mathrm{~mm}$ with about half of the cells having only $100 \mathrm{~mm}$ or less, and there is a continuation of WI diversity loss towards the warmer end with only regions IV and V being present and extensive areas considered as too warm for wine production.

In Fig. 4, sets of histograms for the grapevine mean growing season temperature (Tgs), precipitation (Pgs) and Winkler index (WI) are shown as derived for the mapped
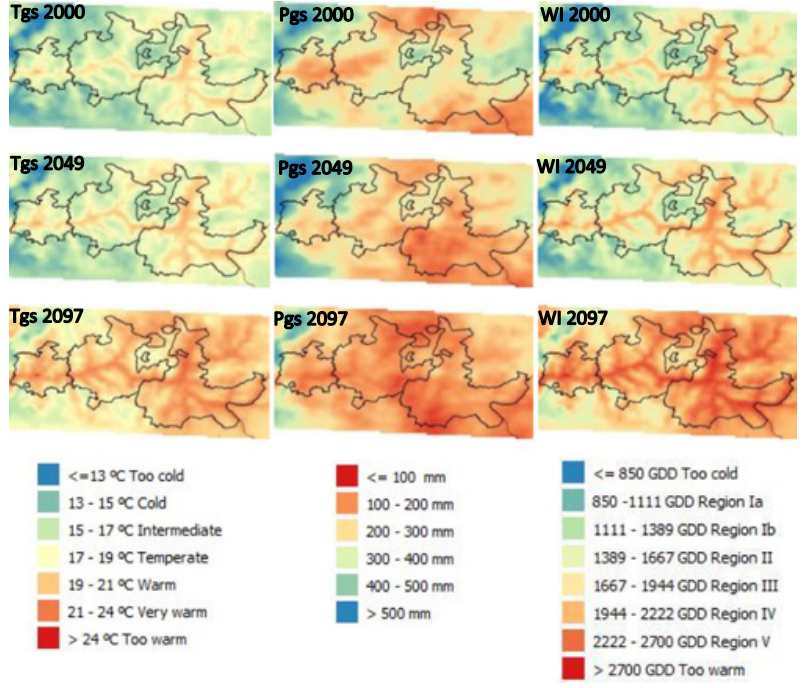

Figure 3. Grapevine mean growing season temperature (Tgs), precipitation (Pgs) and Winkler index (MI) thematic layers derived from very high-resolution $1 \mathrm{~km} \times 1 \mathrm{~km}$ WRF-MPI RCP 8.5 hourly simulations for selected representative recent-past (2000), mid-term future (2049) and long-term future (2097) years in the Portuguese Douro Demarcated Region (DDR).

vineyard areas present in the DDR which were identified by overlaying the Portuguese CORINE 2009 landuse map over the very high-resolution $1 \mathrm{~km} \times 1 \mathrm{~km}$ WRF-MPI RCP 8.5 based thematic layers. Clear shifts toward warmer and drier conditions are observed as previously commented for all the land included within the DDR limits. These shifts become more pronounced from the mid-term 2049 simulation to the long-term future 2097 one.

Figure 5 illustrates the Heliothermal index (HI), the Dryness index (DI) and the Night cold index (CI) thematic layers derived from the very high-resolution $1 \mathrm{~km} \times 1 \mathrm{~km}$ WRF-MPI RCP 8.5 hourly simulations for the selected representative recent-past (2000), mid-term future (2049) and long-term future (2097) years in the Portuguese Douro Demarcated Region (DDR). For the year 2000 recent-past simulation, most cell values within the DDR are associated the temperate, temperate-warm and warm classes with presence of the cooler classes at higher altitudes. The Dryness index (DI) ranges between the very dry and the moderately dry classes with the drier areas associated with topographical valley lows and absence of storms. The night cold index (CI) is also represented almost exclusively by the very cool and cool nights classes with higher values associated with topographical lows especially in the Douro superior sub-region. For the year 2049 mid-term future simulation, HI temperate conditions decrease their presence whereas the temperate-warm and warm classes become more frequent, DI continues to range between the very and the moderately dry classes depending on topography and annual storm coverage, and there is a marked shift in CI from very cool or cool nights conditions to temperate or warm nights conditions.

Finally, the year 2097 long-term MPI-WRF future simulation indicates the disappearance of the temperate and temperate-warm conditions which are substituted by either warm or very warm areas, DI undergoes a marked shift to very dry values conditions throughout all the DDR, 

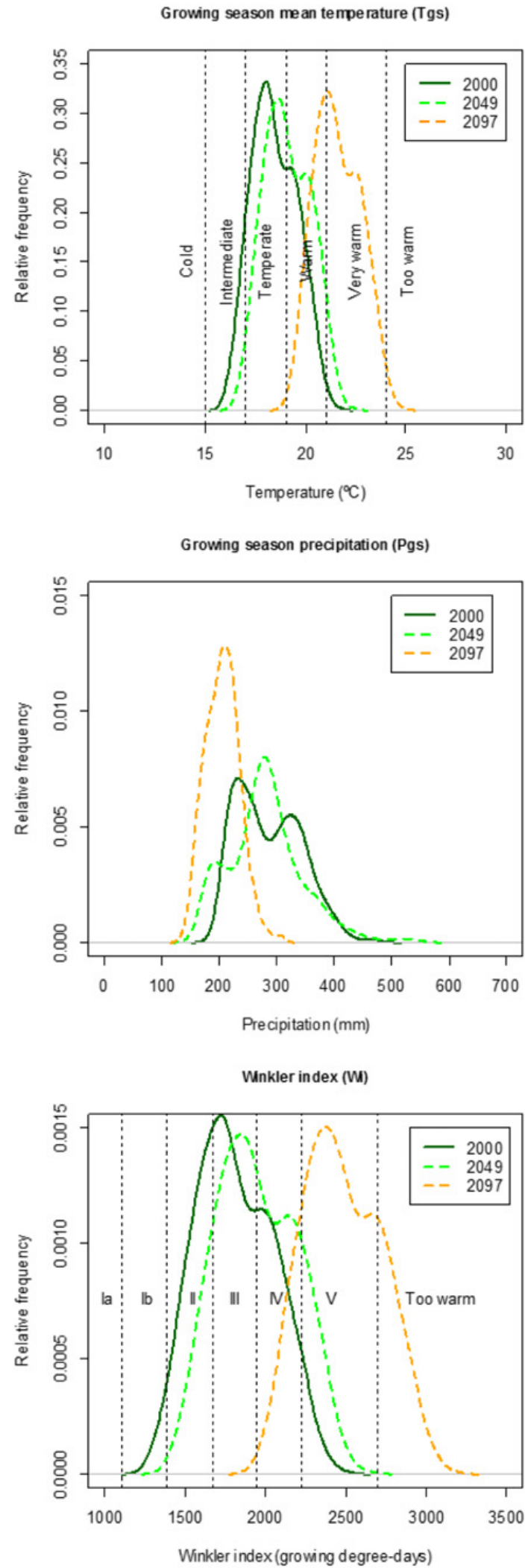

Figure 4. Histograms for the grapevine mean growing season temperature (Tgs), precipitation (Pgs) and Winkler index (WI) derived for mapped vineyard areas as provided by the Portuguese CORINE 2009 dataset overlaid over the very high-resolution $1 \mathrm{~km} \times 1 \mathrm{~km}$ WRF-MPI RCP 8.5 based thematic layers for the selected representative recent-past (2000), mid-term future (2049) and long-term future (2097) years in the Portuguese Douro Demarcated Region (DDR).

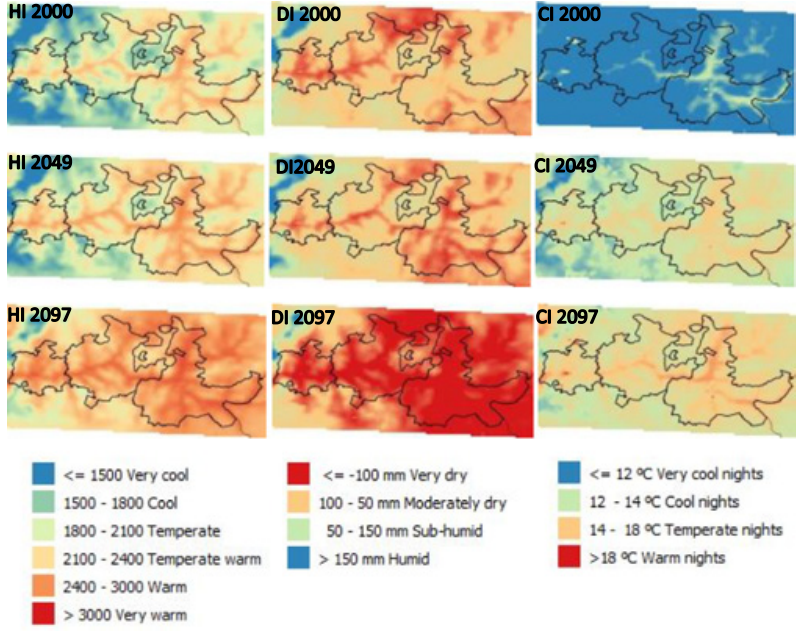

Figure 5. Heliothermal index (HI), Night cold index (CI) and Dryness index (DI) thematic layers derived from very highresolution $1 \mathrm{~km} \times 1 \mathrm{~km}$ WRF-MPI RCP 8.5 hourly simulations for selected representative recent-past (2000), mid-term future (2049) and long-term future (2097) years in the Portuguese Douro Demarcated Region (DDR).

and there is an increase of CI warm nights areas mainly associated to topographical lows.

In Fig. 6, histograms for HI, DI and CI are also presented in relation to the vineyard areas present in the DDR. A gradual shift is observed for HI from the recent-past to the long-term future simulations, $\mathrm{CI}$ changes abruptly at the mid-term future whereas DI does so at the end of the century.

\section{Discussion and conclusions}

In general, the WRF-MPI very high $1 \times 1 \mathrm{~km}$ resolution simulations show an increase in the average temperature during the vegetative period of the grapevine, and a concurrent decrease in growing-season precipitation with the greatest changes taking place at the second half of the XXI century. WI is typical of values associated with the production of high-quality wines in the recent past. However, the future scenarios show a decrease in the diversity of WI regions towards warm or very warm areas associated to the intensive production of wines of intermediate quality, specially by the end of the century. Not surprisingly due to its high correlation to WI, HI also shows a passage from temperate or temperate warm conditions to warm or very warm conditions although this transition is more gradual than in the WI case. In the recent past, CI was associated mainly to very cool nights conditions which are commonly related with the production of quality wines, but since the mid-term future scenario there is also a marked shift to temperate nights conditions reaching even the warm nights conditions for several areas at the end of the century. Finally, DI associates to a similar range of values between the moderately dry and the very dry class during the recentpast and the mid-term future simulations with results apparently associated mainly to the varied topography of the DDR and storm coverage. However, there is a considerable increase of water stress, which is already 


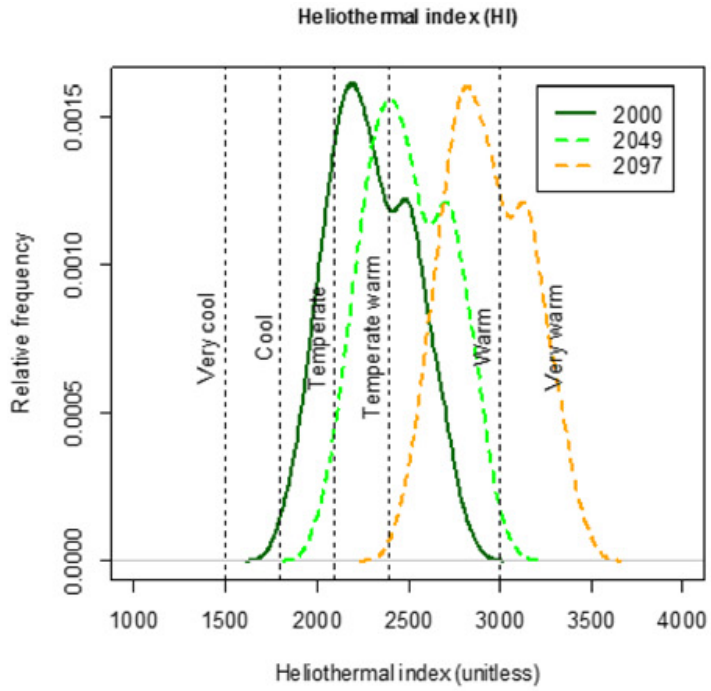

Dryness index (DI)

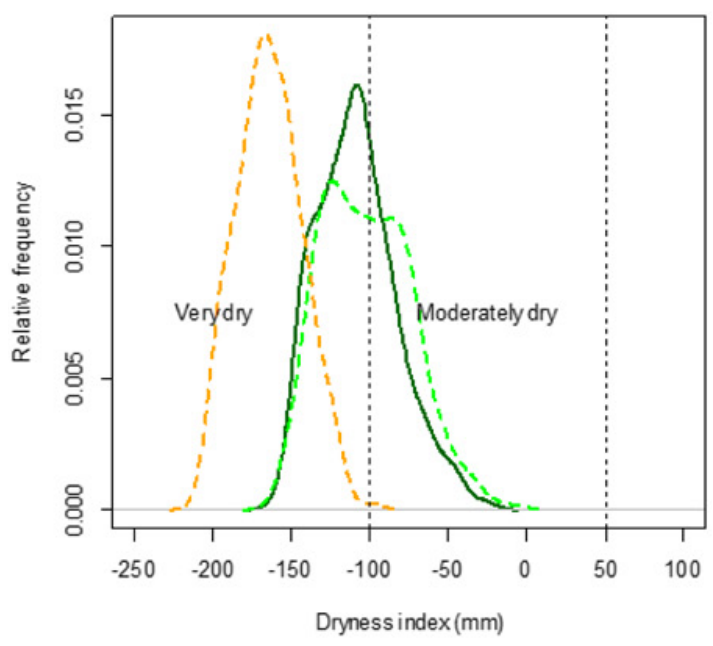

Night cold index (Cl)

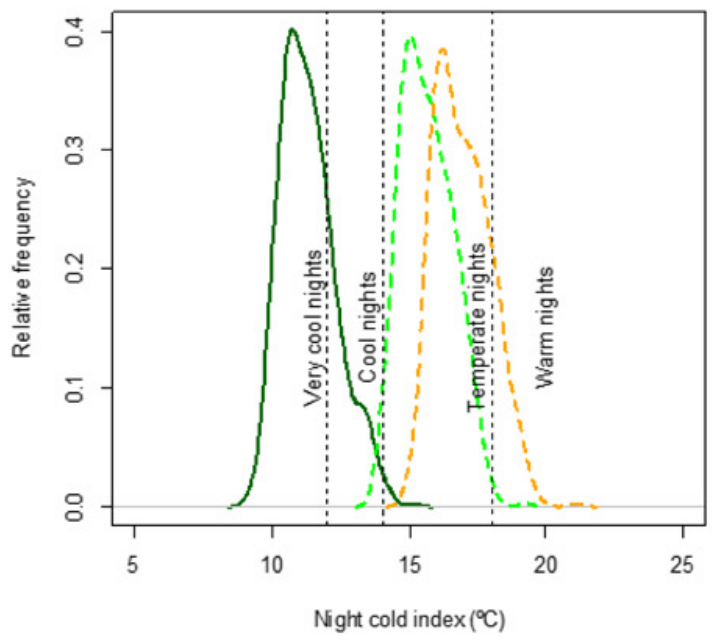

Figure 6. Histograms for the Heliothermal index (HI), the Dryness index (DI) and the Night cold index (CI) as provided by the Portuguese CORINE 2009 dataset overlaid over the very high-resolution $1 \mathrm{~km} \times 1 \mathrm{~km}$ WRF-MPI RCP 8.5 based thematic layers for the selected representative recent-past (2000), midterm future (2049) and long-term future (2097) years in the Portuguese Douro Demarcated Region (DDR). considered high under the present climate, at the end of the century.

Despite lacking the use of coupled phenological and physiological response models for the grapevine, the methodology presented is still useful in providing evidence for future strategies aimed to preserve the high-quality wines in the region and their typicality in a sustainable way. This is so because:

1. It provides the current and future broad picture for the selected grapevine bioclimatic indices in the DDR using conventional standards used worldwide.

2. An advancement on grapevine phenology due to warmer conditions would not be associated with any major relaxation on the natural drought conditions already present and forecasted for the DDR. Furthermore, nocturnal warming could be even greater at phenologically advanced véraison and maturity stages.

It can be considered then that these results provide a high resolution $1 \times 1 \mathrm{~km}$ bioclimatic zoning tool to assess the potential impacts of climate change in the DDR. The shifts towards lower bioclimatic diversity and warmer and drier labels of the MCC system are also in general agreement with previous studies performed in the area by using an ensemble of global $25 \times 25 \mathrm{~km}$ 2041-2070 RCM driven by 3 different GCMs produced by the ENSEMBLES project under the A1B emission scenario downscaled to $1 \times 1 \mathrm{~km}$ resolution by using bicubic interpolation [8]. As the carbon dioxide concentrations and global temperature change are greater in the RCP8.5 emission scenario, the forecasted impacts on grapevine bioclimatic indices are also of greater extent.

These results do not necessarily imply a dramatic decrease of viticultural suitability in the DDR in the mid-term and long-term future scenarios as adaptive measurements can be taken and are already being taken by the grapevine growers in the area, and there is also a constant evolution on wine consumer's preferences [22]. In this sense, several actions can be proposed to preserve as much as possible the DDR wine typicity taking current state-of-the-art knowledge [1] and previous work done in the study area $[11,14,23,24]$ :

1. Delay phenology by clonal selection, suitable rootstocks, and late-ripening local varieties or carefully selected non-local varieties.

2. Training systems and late pruning can also be useful to delay phenology and reduce water deficit.

3. Increase the soil water-holding capacity (SWHC) and select drought resistant rootstocks.

4. Carefully assess the need for irrigation as it has an economic, environmental and social cost.

The authors wish to thank the financial support of the DOUROZONE project (PTDC/AAG-MAA/3335/2014; POCI01-0145-FEDER-016778) through the Project 3599 - Promoting the scientific production and the technological development, and thematic networks (3599-PPCDT) and through FEDER, and the national funds from FCT-Science and Technology Portuguese Foundation for the doctoral grants of 
Blanco-Ward, D. (SFRH/BD/139193/2018) and Silveira, C. (SFRH/BD/112343/2015). Thanks, are also due for the financial support to CESAM (UID/AMB/50017 - POCI-01-0145-FEDER007638), to FCT/MEC through national funds (PIDDAC), and the co-funding by the FEDER, within the PT2020 Partnership Agreement and Compete 2020.

\section{References}

[1] C. Van Leeuwen, P. Darriet, J. Wine Econ. 11, 150 (2016)

[2] M.A. Amerine, A.J. Winkler, Hilgardia 15, 493 (1944)

[3] R.S. Jackson, Wine Science: Principles and Applications, 3rd edn. (Elsevier, San Diego, 2008)

[4] J. Tonietto, A. Carbonneau, Agric. For. Meteorol. 124, 81 (2004)

[5] A. Malheiro, J. Santos, H. Fraga, J. Pinto, Clim. Res. 43, 163 (2010)

[6] R.J. Hijmans, S.E. Cameron, J.L. Parra, P.G. Jones, A. Jarvis, Int. J. Climatol. 25, 1965 (2005)

[7] E.J.M. Van Den Besselaar, M.R. Haylock, G. Van Der Schrier, A.M.G. Klein Tank, A.M.G. Klein, J. Geophys. Res. 116 (2011)

[8] H. Fraga et al., Reg. Environ. Chang. 14, 295 (2014)

[9] Z.M. Moss, R. Babiker, M. Brinkman, S. Calvo, E. Carter, T. Edmonds, J. Elgizouli, I. Emori, S. Erda, L. Hibbard, K. Jones, R. Kainuma, M. Kelleher, J. Lamarque, J.F. Manning, M. Matthews, B. Meehl, J. Meyer, L. Mitchell, J. Nakicenovic, N. O'Neill, B. Pichs, R. Riahi, K. Rose, S. Run, "Towards new scenarios for analysis of emissions, climate change, impacts, and response strategies. IPCC Expert meeting report. Temperature change. Precipitation change Sea Level Rise Extreme events," 2008

[10] N. Nakicenovic et al., "Special Report on Emissions Scenarios A Special Report of Working Group III of thee Intergovernmental Panel on Climate Change," 2000 [Online]. Available: https://www.ipcc.ch/pdf/special-reports/ emissions_scenarios.pdf. [Accessed: 27-Jul2017]

[11] G. Jones, "Uma Avaliação do Clima para a Região Demarcada do Douro?: Uma análise das condições climáticas do passado, presente e futuro para a produção de vinho," ADVID, Peso da Régua, 2013
[12] IVDP (Instituto dos Vinhos do Douro e Porto), "Areas dedicated to grapevine cultivation. Statistics for the year 2016," 2017 [Online]. Available: https://www.ivdp.pt. [Accessed: 18-Apr-2017]

[13] A. Corte-Real, J. Borges, J.S. Cabral, G.V. Jones, Int. J. Climatol. (2016)

[14] G.V. Jones, F. Alves, Int. J. Glob. Warm. 4, 383 (2012)

[15] A. Corte-Real, PhD. thesis, University of Porto (2014)

[16] D. Blanco-Ward, J.M.G. Queijeiro, G.V. Jones, Vitis 46, 63 (2007)

[17] P. Climaco, J. Ricardo-da-Silva, O. Laureano, J. Tonietto, "O clima vitícola das principais regiões produtoras de uvas para vinho de Portugal.," in Clima, zonificación, y tipicidad del vino en regiones vitivinícolas Iberoamericanas., edited by V. Tonietto, J. Sotés Ruiz, V. Gómez-Migues, Ed. Programa Iberoamericano de Ciencia y Tecnología para el Desarrollo (CYTED) (2012), 315

[18] M. Marta-Almeida, J. Teixeira, M.J. Carvalho, P. Melo-Gonçalves, A.M. Rocha, Phys. Chem. Earth 94, 94 (2016)

[19] M.A. Giorgetta et al., J. Adv. Model. Earth Syst. 5, 572 (2013)

[20] IPPC (International Panel on climate Change), "Climate Change 2013. The Physical Science Basis," 2013 [Online]. Available: http://www.ipcc.ch/ report/ar5/wg1/

[21] G.H. Hargreaves, F. Asce, R.G. Allen, J. Irrig. Drain Eng. 129, 53 (2003)

[22] C. van Leeuwen et al., Proc. Natl. Acad. Sci. 110, E3051 (2013)

[23] A.C. Ribeiro et al., "Physiological response of the grapevine cultivars Touriga Nacional and Touriga Franca to increasing summer stress conditions in the Douro," in XIIth International Terroir Congress, Zaragoza, 18th-22nd of June 2018, 2018, no. Cc, p. 4

[24] C. Gonçalves, Igor; Morais, Ana; Teixeira, Bruno; Santos, Paulo; Soares, Rui; Carlos, "Rega deficitária na casta touriga nacional na região demarcada do douro. respostas fisiológicas e efeitos na produtividade e na qualidade da uva," in $10^{\circ}$ Simpósio de Vitivinicultura do Alentejo, 4 - 6 May, 2016, p. 8 